\title{
A Case of Focal Segmental Glomerulosclerosis With Immune Complexes: Is HIV, Hepatitis B, or Crack the Culprit?
}

Patil Balozian ${ }^{1}$, Abdul Rahman Al Armashi ${ }^{1}$, Mohammad Haidous ${ }^{1}$, Massiel Cruz-Peralta ${ }^{1}$, Keyvan Ravakhah $^{1}$

1. Internal Medicine, St. Vincent Charity Medical Center, Cleveland, USA

Corresponding author: Patil Balozian, patilbaliozian92@gmail.com

\begin{abstract}
Human immunodeficiency virus (HIV)-positive individuals are at an increased risk for kidney diseases, including HIV-associated nephropathy (HIVAN), focal segmental glomerulosclerosis (FSGS), HIV immune complex disease of the kidney (HIVICK), and acute tubular necrosis (ATN). Non-modifiable factors such as age and genetics, as well as modifiable factors such as illicit drug use and compliance, define the progression to renal failure. The patient is a 64-year-old African American male with HIV, treated latent syphilis, chronic kidney disease stage 3a, and cocaine use disorder who presented with shortness of breath, bilateral lower extremities swelling, and fatigue with normal vitals and a physical exam remarkable for bibasilar inspiratory crackles with peripheral edema. Laboratory tests showed creatinine $(\mathrm{Cr})$ of $2.23 \mathrm{mg} / \mathrm{dL}$ with a baseline of 1.5 $\mathrm{mg} / \mathrm{dL}$, albumin of 1.8 , blood natriuretic peptide (BNP) of 667.88 , and lipidemia. His urine was remarkable for proteinuria and microalbuminuria in the presence of cocaine. Immunofixation electrophoresis showed a marked increase in IgG and IgM, free lambda, and free kappa/free lambda ratio with HIV viral load of 39,400 copies/ml, absolute CD4 count of 56, and an acute hepatitis B panel. Renal biopsy confirmed HIVAN with FSGS accompanied by collapsing features, HIVICK, and ATN. The patient was subsequently started on highly active antiretroviral therapy (HAART) with prophylactic antibiotics and close monitoring.
\end{abstract}

Categories: Internal Medicine, Infectious Disease, Nephrology

Keywords: hiv associated nephropathy (hivan), hiv-associated immune complex kidney disease (hivick), non collapsing focal segmental glomerulosclerosis (fsgs), polyclonal gammopathy, light chains, nephropathy, proteinuria, immune-complex kidney disease, acute tubular necrosis (atn), human immunodeficiency virus-1(hiv-1)

\section{Introduction}

Human immunodeficiency virus type 1 (HIV-1) seropositive patients are at an increased risk for kidney diseases, including HIV-associated nephropathy (HIVAN), focal segmental glomerulosclerosis (FSGS), HIV immune complex disease of the kidney (HIVICK), and acute tubular necrosis (ATN). Nonmodifiable factors such as age and genetics, as well as modifiable factors such as illicit drug use and compliance, define the progression to renal failure. The most common cause of chronic renal failure in HIV-1-seropositive patients is HIVAN, almost exclusively seen in black patients. It was primarily described in 1984 by Rao et al. and Pardo et al. in New York and Miami and is currently a definite clinical and histopathologic entity [1-3]. In this article, we present the case history of a 64-year-old African American male with HIV who presented with nephropathy and was found to have HIVAN, HIVICK, and ATN.

(c) Copyright 2021 Balozian et al. This is an open access article distributed under the terms of the Creative Commons Attribution License CC-BY 4.0., which permits unrestricted use, distribution, and reproduction in any medium, provided the original author and source are credited.

\section{Case Presentation}

The patient is a 64-year-old African American man with HIV, treated latent syphilis, chronic kidney disease stage $3 \mathrm{a}$, and cocaine use disorder who presented with progressive, exertional shortness of breath, orthopnea, paroxysmal nocturnal dyspnea, bilateral lower extremities swelling, and fatigue of a couple of weeks duration. Review of systems was unremarkable. He reported non-compliance to HIV medications for the past three years (diagnosed 17 years ago) and had no scheduled medications. The patient was vitally stable with a physical exam remarkable for bibasilar inspiratory crackles and +2 pitting edema on lower extremities. Laboratory tests (Table 1) showed normal hemoglobin, creatinine ( $\mathrm{Cr}$ ) of $2.23 \mathrm{mg} / \mathrm{dL}$ with a baseline of $1.5 \mathrm{mg} / \mathrm{dL}$, blood urea nitrogen (BUN) of 27 with a glomerular filtration rate of $36 \mathrm{~mL} / \mathrm{min}$, albumin of $1.8 \mathrm{~g} / \mathrm{dl}$, blood natriuretic peptide (BNP) of $667.88 \mathrm{ng} / \mathrm{ml}$, and lipidemia. His urine was remarkable for proteinuria with a microalbumin/creatinine ratio of $3364.2 \mathrm{mcg} / \mathrm{mg}$ in the presence of cocaine. Immunofixation electrophoresis showed a marked increase in IgG and IgM with a mild increase in free kappa, free lambda, and free kappa/free lambda ratio. Antineutrophil cytoplasmic antibodies (ANCA), myeloperoxidase antibody, proteinase 3 (PR3) antibody, C3, and C4 were normal. HIV viral load was 39,400 copies/ml with an absolute CD4 count of 56 . Hepatitis B surface antigen and hepatitis B e antigen were positive. Echocardiography showed diastolic heart failure with preserved ejection fraction and the patient was started on intravenous furosemide for symptomatic relief. 


\section{Cureus}

\begin{tabular}{|c|c|c|}
\hline Preliminary Laboratory work & Value & Reference range \\
\hline Hemoglobin & $13.7 \mathrm{~g} / \mathrm{dl}$ & $14.0-16.5 \mathrm{~g} / \mathrm{dl}$ \\
\hline Creatinine & $2.23 \mathrm{~g} / \mathrm{dl}$ & $0.70-1.30 \mathrm{~g} / \mathrm{dl}$ \\
\hline BUN & $27 \mathrm{mg} / \mathrm{dl}$ & 7-18 mg/dl \\
\hline Albumin & $1.8 \mathrm{~g} / \mathrm{dl}$ & $2.9-4.4 \mathrm{~g} / \mathrm{dl}$ \\
\hline Cholesterol & 218 mg/dl & $<200 \mathrm{mg} / \mathrm{dl}$ \\
\hline LDL Cholesterol & 141 mg/dl & $60-130 \mathrm{mg} / \mathrm{dl}$ \\
\hline BNP & $667.88 \mathrm{ng} / \mathrm{ml}$ & $0.01-0.045 \mathrm{ng} / \mathrm{ml}$ \\
\hline Urine Studies & Value & Reference range \\
\hline White Blood Count & 11-15/ High Power Field & 0-5/ High Power Field \\
\hline Urine Protein & $100 \mathrm{mg} / \mathrm{dl}$ & Negative \\
\hline Random Creatinine & $29.10 \mathrm{mg} / \mathrm{dl}$ & $30-115 \mathrm{mg} / \mathrm{dl}$ \\
\hline Random Microalbumin & $979.0 \mathrm{mg} / \mathrm{dl}$ & $<30 \mathrm{mg} / \mathrm{dl}$ \\
\hline Creatinine & $29.1 \mathrm{mg} / \mathrm{dl}$ & 30-115 mg/dl \\
\hline Microalbumin/Creatinine & $3364.2 \mathrm{mcg} / \mathrm{mg}$ & $0-30 \mathrm{mcg} / \mathrm{mg} \mathrm{CR}$ \\
\hline Cocaine Screen & Positive & Negative \\
\hline Immunology & Value & Reference range \\
\hline Immunofluorescence IgG & $4085 \mathrm{mg} / \mathrm{dl}$ & $603-1613 \mathrm{mg} / \mathrm{dl}$ \\
\hline Immunofluorescence IgA & $216 \mathrm{mg} / \mathrm{dl}$ & $61-437 \mathrm{mg} / \mathrm{dl}$ \\
\hline Immunofluorescence IgM & 469 mg/dl & 20-172 mg/dl \\
\hline Anti-Proteinase 3 & $<3.5 \mathrm{U} / \mathrm{ml}$ & $0-3.5 \mathrm{U} / \mathrm{ml}$ \\
\hline Atypical p-ANCA & $<1: 20$ titer & $<1: 20$ titer \\
\hline p-ANCA antibody & $<1: 20$ titer & $<1: 20$ titer \\
\hline Myeloperoxidase antibody & $<9 \mathrm{U} / \mathrm{ml}$ & $0-9 \mathrm{U} / \mathrm{ml}$ \\
\hline ANCA & 1:40 titer & $<1: 20$ titer \\
\hline Complement C3 & 112 mg/dl & $90-180 \mathrm{mg} / \mathrm{dl}$ \\
\hline Complement C4 & $19.2 \mathrm{mg} / \mathrm{dl}$ & $10-40 \mathrm{mg} / \mathrm{dl}$ \\
\hline CD4 Cells (\% percentage) & 6 (\% percentage) & 30-61 (\% percentage) \\
\hline Absolute CD4 count & 56 cells/ul & 490-1740 cells/ul \\
\hline Free Kappa Light Chain & $351.8 \mathrm{mg} / \mathrm{L}$ & $3.3-19.4 \mathrm{mg} / \mathrm{L}$ \\
\hline Free Lambda Light Chain & $167.5 \mathrm{mg} / \mathrm{L}$ & $5.7-26.3 \mathrm{mg} / \mathrm{L}$ \\
\hline Free Kappa/Lambda Ratio & 2.10 & $0.26-1.65$ \\
\hline Serology & Value & Reference Range \\
\hline Hepatitis Bs Antigen & Positive & Negative \\
\hline Hepatitis Be Antigen & Positive & Negative \\
\hline Hepatitis Be Antibody & Negative & Negative \\
\hline HIV RNA copies/ml Ultra & 39400 & $20-10,000,000$ copies/ \\
\hline HIV-1 RNA (PCR) log 10 & 4.595 & Log10 copy/ml \\
\hline
\end{tabular}

\section{TABLE 1: Laboratory Work}




\section{Cureus}

BUN: blood urea nitrogen, LDL: low-density lipoprotein, ANCA: anti-neutrophil cytoplasmic antibodies, PCR: polymerase chain reaction

Renal ultrasound showed increased parenchymal echogenicity in both kidneys followed by a right renal biopsy that revealed FSGS with collapsing features, acute tubular injury, and mild to moderate interstitial fibrosis. There were 17 glomeruli, two of which were completely sclerotic with findings of focal and mild mesangial hypercellularity. Up to five glomeruli had features of focal segmental glomerulosclerosis, including bowman's capsular adhesions, segmentally solidified capillary lumina, and urinary space collagen (Figure 1). In addition, there was mild to moderate mononuclear cell inflammation noted in the interstitium with non-atrophic tubules showing features of injury such as apical cytoplasmic blebbing, broken brush borders, and tubular cell mitotic figures (Figure 2).

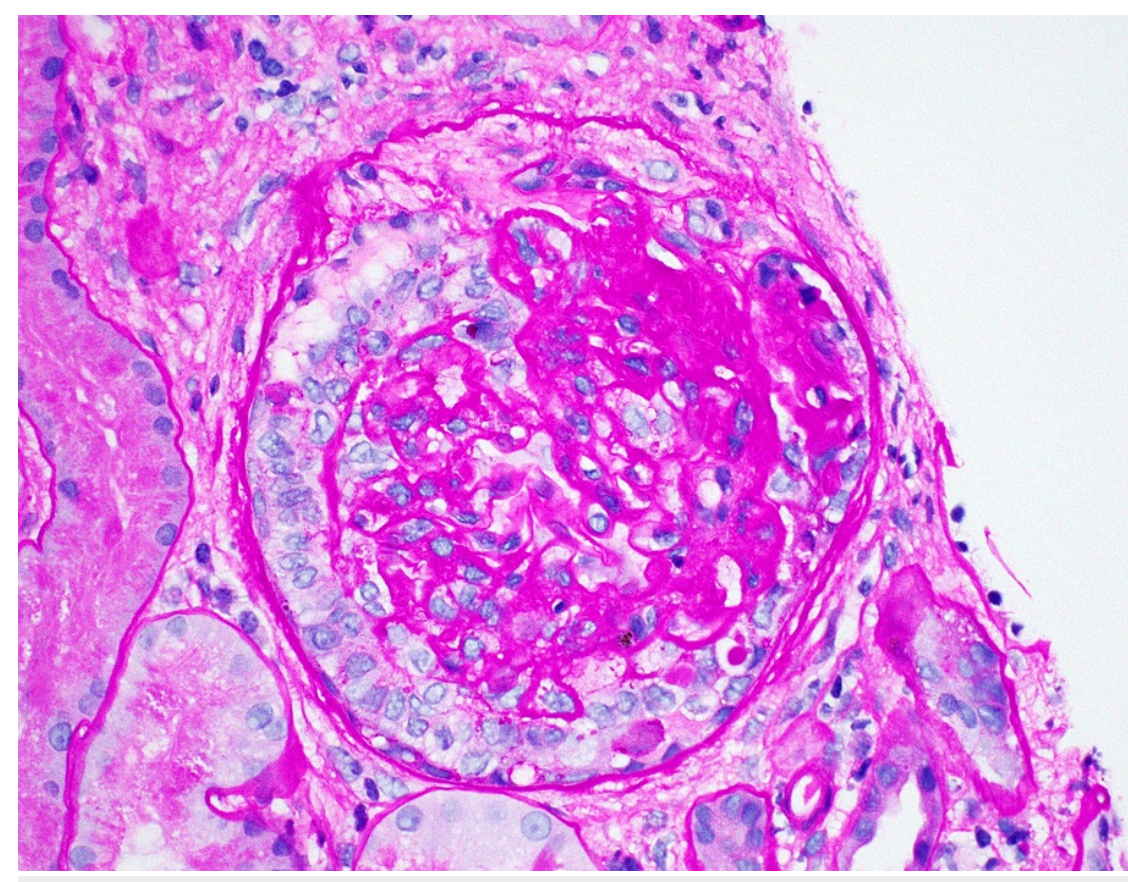

\section{FIGURE 1: Renal Biopsy}

Renal biopsy histology demonstrated segmental sclerosis with crescentic features indicative of focal segmental glomerulosclerosis. 


\section{Cureus}

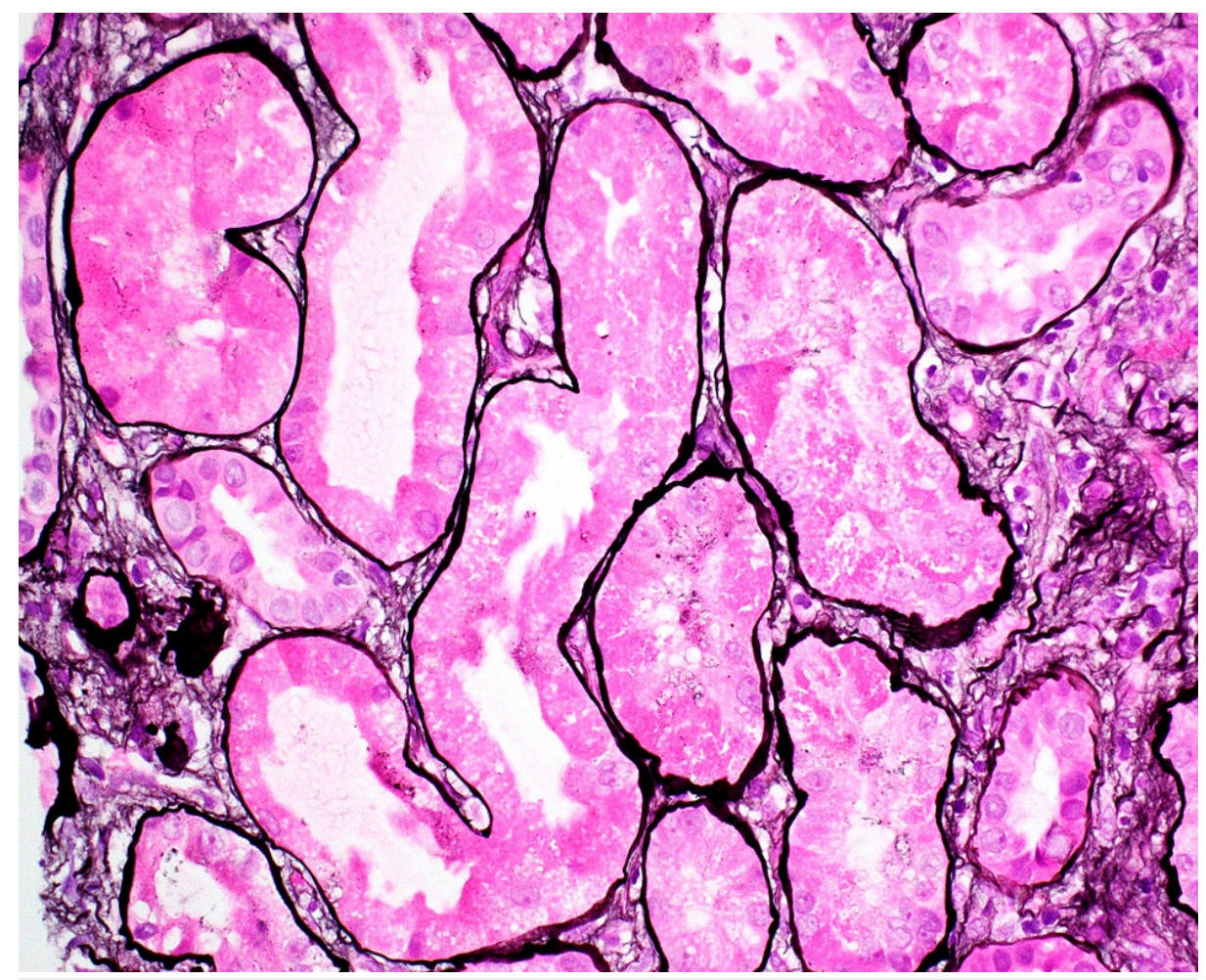

\section{FIGURE 2: Renal Biopsy}

Renal biopsy histology demonstrated denudation of renal tubular cells and loss of brush borders.

Immunofluorescence microscopy consisted of mesangial regions and capillary walls staining mostly for IgA and IgM. Three out of 11 glomeruli were completely sclerotic with mesangial regions and capillary walls staining for IgA (1+), IgM (3+), C3 (trace), kappa (trace to $1+$ ), and lambda (trace to $1^{+}$) in a granular pattern (Figure 3). Tubular epithelial cell protein reabsorption droplets were stained for albumin (3+), kappa (1 to $2+$ ), and lambda (1 to $2+$ ). 


\section{Cureus}

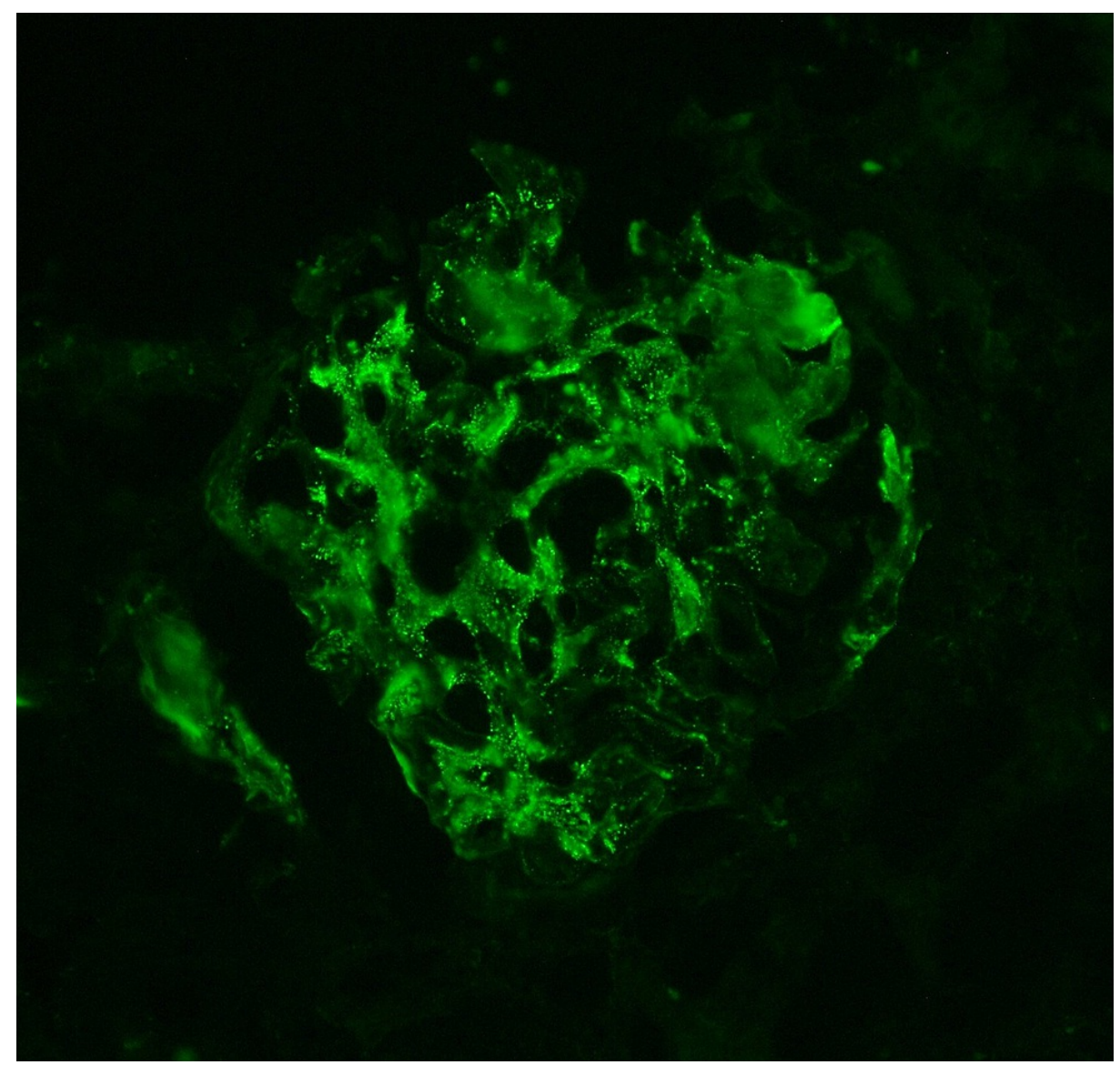

\section{FIGURE 3: Immunofluorescence Microscopy}

Immunofluorescence microscopy demonstrated mesangial regions stained for $\operatorname{lgA}(1+), \lg M(3+)$, C3 (trace), kappa (trace to 1+), and lambda (trace to 1+) in a granular pattern.

Electron microscopy demonstrated extensive effacement of podocyte foot processes. Electron dense deposits were located in mesangial regions with few in the subendothelial, subepithelial, and intramembranous regions (Figure 4). Glomerular basement membrane had the normal trilaminar structure with moderate thickening. 


\section{Cureus}

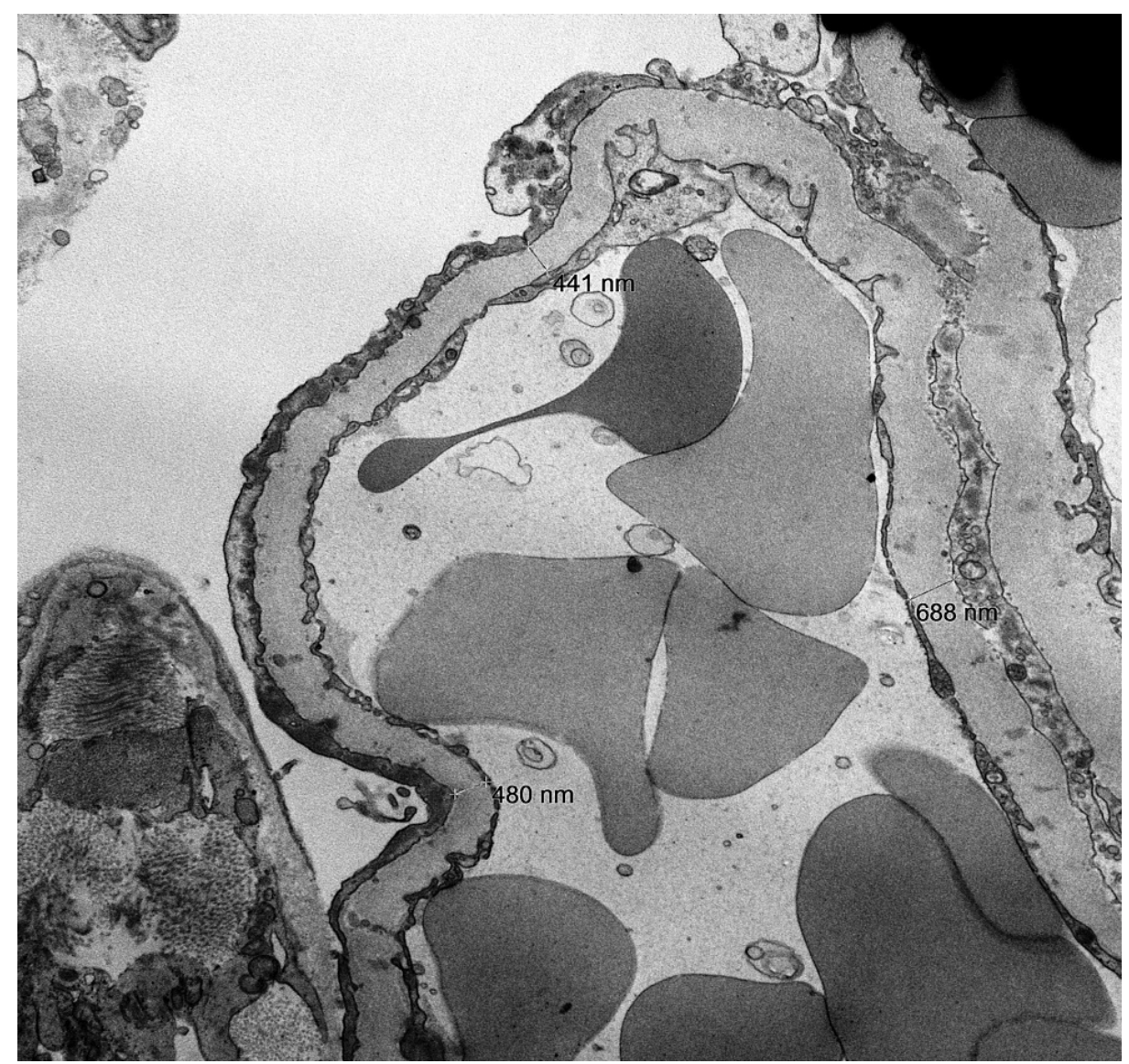

\section{FIGURE 4: Electron Microscopy}

Electron microscopy demonstrated effacement of podocyte foot processes with electron dense deposits in the mesangial, subendothelial, subepithelial and intramembranous regions.

The patient was observed to have HIVAN and FSGS with collapsing features, HIVICK, and ATN. He improved symptomatically throughout his hospitalization, was discharged on highly active antiretroviral therapy (HAART) with prophylactic antibiotics, and was recommended to follow up very closely with nephrology and infectious disease specialists.

\section{Discussion}

HIVAN is a distinct clinicopathologic syndrome predominantly involving African American patients. Susceptibly to genetic mutations of APOL1 in patients of African descent is associated with the development of FSGS [4]. As per the literature, patients with HIVAN are mostly black with $\mathrm{CD} 4<200 / \mathrm{mL}(\mathrm{P}=$ $0.01)$ and glomerular filtration rate $<30 \mathrm{~mL} / \mathrm{min} / 1.73 \mathrm{~m}^{2}(\mathrm{P}<0.01)$ [5]. HIVAN's overall prevalence varies according to the population's demographic features with $\sim 10 \%$ to $15 \%$ of HIV-infected patients developing HIVAN [1].

HIVAN can occur at any stage of the HIV infection, although most patients show significant immunosuppression and advanced infection at the time of the diagnosis. Its histopathologic features are represented in about $80 \%$ of cases by focal segmental glomerulosclerosis with collapse of the glomerular tuft in some glomeruli without prominent mesangial expansion or basement membrane thickening, extensive tubular ectasia, and tubulointerstitial changes [1].

The occurrence of hepatitis B, being a well-known cause of membranous nephropathy (MN), has also been reported in FSGS [6]. There have been previous cases, seven reported, two of which demonstrated hepatitis B surface antigen in the renal tissue and a response to lamivudine, indicating a possible causal association between the viral infection and occurrence of nephrotic syndrome [7]. As to the patient's cocaine use disorder, it is likely the contributing etiology of his ATN [8]. Also, his panel depicts a polyclonal gammopathy that is not uncommonly reported in patients with HIV infection. Polyclonal hypergammaglobulinemia in turn promotes the development of circulating immune complexes, their passive trapping, or the in situ deposition of the antibodies binding to HIV viral antigens [9]. 
In terms of pathogenesis, HIV nucleic acid in podocytes, parietal epithelial cells, tubular epithelial cells, Tcells, and macrophages in human HIVAN renal biopsy specimens support the presence of the HIV gene. The kidney acts as a compartment separate from the blood where HIV-1 can replicate even in patients with serological remission [10].

Clinically, the classic presentation of HIVAN includes rapidly progressive renal failure, moderate to nephrotic range proteinuria, bland urinary sediment, and ultrasound findings of large, highly echogenic kidneys [11]. Studies regarding the optimal treatment of HIVAN with HIVICK patients involve initiation of HAART, steroids, and angiotensin-converting enzyme inhibitors [12]. In multivariate analysis, HIVAN risk was reduced by $60 \%$ ( $95 \%$ CI, 30 to $80 \%$ ) by use of HAART, and no patient developed HIVAN when HAART had been initiated prior to the development of AIDS [13]. Also, the pathogenic role of HIV replication in the development of HIVICK for patients on HAART reveals improvement of kidney function in patients who have detectable HIV RNA at the time that HIVICK diagnosis has been studied [14].

\section{Conclusions}

This case highlights that HIV-positive patients are at an increased risk of developing complex focal glomerular, immune, and tubular kidney pathologies, especially in the setting of acute infections, drugs, and non-compliance. HIVAN and HIVICK can coexist in some cases, mostly in the context of patients being off HAART with low CD4 counts and high viral loads. Hepatitis B could cause FSGS in a small percentage of patients, less likely in our patient's case. Cocaine use disorder contributes to ATN. Nephrologists and infectious disease specialists should work together to screen a seropositive population with important proteinuria $(>1 \mathrm{~g} / 24 \mathrm{~h}$ ) consistent with HIVAN and confirm the diagnosis by renal biopsy. Although therapies for this condition have produced contradicting results, HAART may prolong nephropathic patient survival. Keen follow-up of proteinuria and kidney function remains vital.

\section{Additional Information \\ Disclosures}

Human subjects: Consent was obtained or waived by all participants in this study. Conflicts of interest: In compliance with the ICMJE uniform disclosure form, all authors declare the following: Payment/services info: All authors have declared that no financial support was received from any organization for the submitted work. Financial relationships: All authors have declared that they have no financial relationships at present or within the previous three years with any organizations that might have an interest in the submitted work. Other relationships: All authors have declared that there are no other relationships or activities that could appear to have influenced the submitted work.

\section{References}

1. Calza L, Manfredi R, Francesco C: HIV-associated nephropathy with peripheral edema, arterial hypertension, and hyperlipidemia: case report and literature review. Infect Dis Clin Pract. 2002, 11:459-64. 10.1097/01.idc.0000086418.30743.63

2. Rao TK, Filippone EJ, Nicastri AD, Landesman SH, Frank E, Chen CK, Friedman EA: Associated focal and segmental glomerulosclerosis in the acquired immunodeficiency syndrome. N Engl J Med. 1984, 310:669-73. 10.1056/NEJM198403153101101

3. Pardo V, Aldana M, Colton RM, et al.: Glomerular lesions in the acquired immunodeficiency syndrome. Ann Intern Med. 1984, 101:429-34. 10.7326/0003-4819-101-4-429

4. Goto D, Ohashi N, Takeda A, Fujigaki Y, Shimizu A, Yasuda H, Ohishi K: Case of human immunodeficiency virus infection presenting as a tip variant of focal segmental glomerulosclerosis: a case report and review of the literature. World J Nephrol. 2018, 7:90-5. 10.5527/wjn.v7.i4.90

5. Lescure FX, Flateau C, Pacanowski J, et al.: HIV-associated kidney glomerular diseases: changes with time and HAART. Nephrol Dial Transplant. 2012, 27:2349-55. 10.1093/ndt/gfr676

6. Sakai K, Morito N, Usui J, et al.: Focal segmental glomerulosclerosis as a complication of hepatitis B virus infection. Nephrol Dial Transplant. 2011, 26:371-3. 10.1093/ndt/gfq600

7. Khaira A, Upadhyay BK, Sharma A, et al.: Hepatitis B virus associated focal and segmental glomerular sclerosis: report of two cases and review of literature. Clin Exp Nephrol. 2009, 13:373-7. 10.1007/s10157008-0124-8

8. Bahaa Aldeen M, Talibmamury N, Alalusi S, Nadham O, Omer AR, Smalligan RD: When coke is not hydrating: cocaine-induced acute interstitial nephritis. J Investig Med High Impact Case Rep. 2014, 2:2324709614551557. 10.1177/2324709614551557

9. Cohen SD, Kimmel PL: Immune complex renal disease and human immunodeficiency virus infection. Semin Nephrol. 2008, 28:535-44. 10.1016/j.semnephrol.2008.08.006

10. Medapalli RK, He JC, Klotman PE: HIV-associated nephropathy: pathogenesis. Curr Opin Nephrol Hypertens. 2011, 20:306-11. 10.1097/MNH.0b013e328345359a

11. Wyatt CM, Klotman PE, D'Agati VD: HIV-associated nephropathy: clinical presentation, pathology, and epidemiology in the era of antiretroviral therapy. Semin Nephrol. 2008, 28:513-22. 10.1016/j.semnephrol.2008.08.005

12. Kalayjian RC: The treatment of HIV-associated nephropathy . Adv Chronic Kidney Dis. 2010, 17:59-71. 10.1053/j.ackd.2009.08.013

13. Palau L, Menez S, Rodriguez-Sanchez J, Novick T, Delsante M, McMahon BA, Atta MG: HIV-associated nephropathy: links, risks and management. HIV AIDS (Auckl). 2018, 10:73-81. 10.2147/HIV.S141978 


\section{Cureus}

14. Booth JW, Hamzah L, Jose S, et al.: Clinical characteristics and outcomes of HIV-associated immune complex kidney disease. Nephrol Dial Transplant. 2016, 31:2099-107. 10.1093/ndt/gfv436 